\title{
The Impact of Energy Prices on Industrial Energy Efficiency and Productivity
}

by

Gale A. Boyd

Presented to the

Workshop on Partnerships for

Industrial Productivity through

Energy Efficiency

Argonne National Laboratory

Energy Policy Section

Decision and Information Sciences Division

Work sponsored by the United States Department of Energy, Deputy Assistant Secretary of Energy Efficiency and Renewable Energy, Office of Industrial Technology, and the Energy Information Administration, Energy Analysis and Forecasting Division under contract number W-31-109-Eng-38 


\section{THE IMPACT OF ENERGY PRICES ON INDUSTRIAL ENERGY EFFICIENCY AND PRODUCTIVITY Gale Boyd}

\section{INTRODUCTION}

Energy prices moved into the forefront of concern in the mid and late seventies when two oil price shocks drove up energy prices dramatically. The analysis of the subsequent increase in industrial energy efficiency, i.e., decline in energy use per unit of industrial output, has filled volumes of govern nent and private studies. Despite the volumes of analysis, there remains no consensu.s on the magnitude of the effect of energy prices on industrial energy efficiency or the effect of the change in energy prices on productivity. This paper will not resolve the issue, but will examine some sources of the controversy to initiate a dialog between policy makers, analysts, and the energy consumers and producers.

It is important initially to observe that energy and industry are not well defined homogeneous entities. Energy takes on different and distinct forms. In particular it is important to distinguish between electric and non-electric energy. For some applications they may be easily interchanged, for others they may not. While this may also be true for the various liquid, gaseous, and solid fuels that comprise non-electric energy, e.g., petroleum distillates, natural gas, coal, biomass etc., this paper will focus only on the distinction between electricity and non-electric energy.

Industry is even more varied than the energy that industry uses to run its furnaces and refrigerators, motors and boilers, lights and computers. When compared to the narrowly defined areas of residential energy use or transportation energy use, industrial energy use might as well be called 'everything else'. The variety of applications of energy to produce the products of the U.S. economy makes it even more difficult to draw broad inferences about the impact of energy prices on industrial energy efficiency and productivity.

Many studies examine industry as an aggregate entity. These types of macro responses are not the subject of this workshop. The macroeconomic, or general equilibrium, response to an energy price change can be much larger than the microeconomic, or partial equilibrium, response. Solow (Solow 1987) illustrates this point with a simulation of a 2-sector economy. He shows that the macro economy can exhibit energy price responsiveness, even when the microsectors are assumed to have no such possibilities. This can occur when the demand for output from the energy intensive sector declines due to increases in the price of its output, after as increase in

Energy Policy Section, Argonne National Laboratory. Work sponsored by the United States Department of Energy, Deputy Assistant Secretary of Energy Efficiency and Renewable Energy, Office of Industrial Technology, and the Energy Information Administration, Energy Analysis and Forecasting Division under contract number W-31109-Eng-38 
energy price. While these responses are important, this workshop is concerned with the response of the microeconomic entity, the firm or some disaggregate sector of industry.

Analyses of the response to energy price changes fall loosely into two categories, econometric and engineering. Econometric analysis uses observed data to statistically correlate prices with demand for energy and other economic inputs. History is used to measure what was 'actually' done, to try to predict what will happen. ingineering analysis mimics the detailed cost comparison that a hypothetical decision maker would use to determine the cost effectiveness of a particular investment. Explicit information about new or emerging energy technologies can be included in engineering models. The attraction is the direct connection to real industry applications, processes, and products. However, when examining the broad nature of all industrial energy use, engineering analysis is very data intensive.

While econometric models can vary in the mathematical form that the equations that are used to estimate the relationship between price and energy use, they are often summarized by the demand elasticity. This is the percentage by which energy demand changes when the price of energy changes by $1 \%$. For example, an elasticity of -0.5 implies a one-half percent drop in energy demand for every one percent increase in price. The dema.ıd elasticity includes the effect of substituting other inputs for energy, including capital investments, labor, or alternative materials. However, there is no specific technological information about how this substitution occurs.

The price responsiveness of engineering energy analysis is typically summarized by the conservation supply curve (CSC). The CSC is derived by ranking the energy savings that may be 'supplied' at a levelized capital cost per unit of energy saved. The $\mathrm{CSC}$ is therefore dependent on some capital recovery factor, internal rate of return, etc. The CSC may also be represented as a cost per flow of energy saved, so that the cost is in the same units at the price of energy. This allows the CSC to determine which engineering project should be (of will be) undertaken at some assumed (forecast) energy price. An example CSC is show in figure 1. Each 'step' on the curve would represent some project that is undertaken to save some specified amount of energy. The $x$-axis is expressed as a percentage of the base amount of energy demand $E_{0}$. The slope of the CSC caries information about price responsiveness that is very similar to the elasticity. If the slope of the CSC is transformed by the base energy price to represent a percentage, this yields a type of demand elasticity.

\section{DISCLAIMER}

\footnotetext{
This report was prepared as an account of work sponsored by an agency of the United States Government. Neither the United States Government nor any agency thereof, nor any of their employees, makes any warranty, express or implied, or assumes any legal liability or responsibility for the accuracy, completeness, or usefulness of any information, apparatus, product, or process diselosed, or represents that its use would not infringe privately owned rights. Reference herein to any specific commercial product, process, or service by trade name, trademark, manufacturer, or otherwise does not necessarily constitute or imply its endorsement, recommendation, or fitvoring by the United States Government or any agency thereof. The views and opinions of authors expressed herein do not necessarily state or reflect those of the United States Government or any agency thereof.
} 


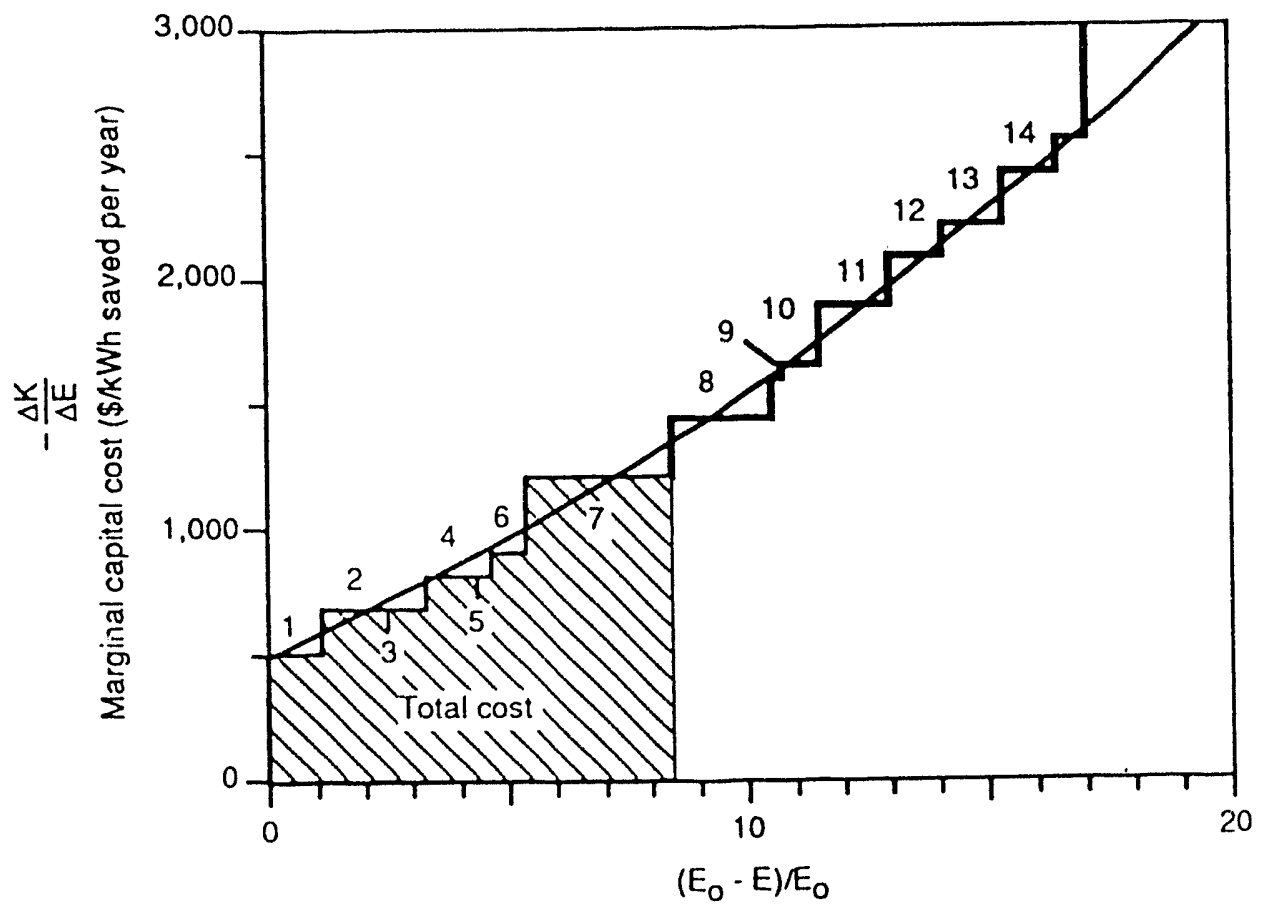

Total energy savings per year (as a percent of base consumption)

Note: Numbers on curve correspond to hypothetical project number.

Figure 1 Example of a Conservation Supply Curve (source: Ross et al 1993) 


\section{EXAMPLE ELASTICITIES FROM ECONOMETRIC STUDIES}

Rather than survey econometric studies in general, this section compares an effort by EPRI (King 1990) to estimate elasticities with a variety of commonly available functional forms and compare them to some of the work at ANL (Boyd, Kokklenberg, and Ross 1991) (Boyd, Kokklenberg, and Ross 1991). The EPRI project, INFORUM Level I, was unique in that it published estimates using the same data set and level of aggregation, 2-digit SIC, for three different functional forms for the dual cost function of the industry. This EPRI study is convenient to illustrate the range of estimates that can arise.

Duality based econometric models, like those used by the EPRI and ANL studies, assume that the underlying production process can be represented by a general mathematical form and that the decision maker is minimizes cost (or maximizes profit). Duality based econometric models rely on Shephard's lemma (Shephard, 1970) or related theorem in duality. Shephard's lemma says that the optimal demand for in input, $X$, is the first derivative of the cost function, $C$, which is dual to the assumed production function. This allows econometric estimates to focus on the cost function, instead of the : anderlying production function. Studies that examine total energy use (E) or total fuel and electricity use $(\mathrm{E}, \mathrm{F})$ often include capital, labor, and materials $(\mathrm{K}, \mathrm{L}, \mathrm{M})$ in prices included in the cost function $\mathrm{C}$.

$$
\begin{aligned}
& \text { Total Cost }=C\left(U, P_{K}, P_{L}, P_{E}, P_{M}\right) \\
& \text { or } \quad=C\left(U, P_{K}, P_{L}, P_{E}, P_{F}, P_{M}\right) \\
& \text { Demand for } X=\frac{\delta C}{\delta P_{X}}
\end{aligned}
$$

Such models rely on an assumed form of the dual cost function and derives a system of demand equations via differentiation. Common forms of the cost or aggregator function are the so-called flexible functional forms, which are based on second order taylor series expansions in output, $\mathrm{U}$, and prices, $\mathrm{P}$.

$$
\sum_{i=1}^{n} \alpha_{i} f\left(P_{i}\right)+\sum_{i=1}^{n} \sum_{j=1}^{n} \beta_{i j} f\left(P_{i}\right) f\left(P_{j}\right)+\gamma_{U} f(U)+\sum_{i=1}^{n} \gamma_{i} f(U) f\left(P_{i}\right)
$$

Specifying the function $f(\cdot)$ to be the natural log gives the TRANSLOG form; Specifying the function $\mathrm{f}(\cdot)$ to be the square root gives the Generalized Leontief form. Shephard's lemma applied to the TRANSLOG form yields cost share equations that are linear in the parameters. The Generalized Leontief form yields factor demand equations that are also linear in parameters, therefore estimatable with commonly available econometric packages. The EPRI study estimates both the TRANSLOG and Generalized Leontief forms. They also estimate a variation of the TRANSLOG that assumes that capital, K, is fixed in the short run. This allows inferences about both the long run and short run energy demand elasticities.

Tables 1 and 2 summarize the elasticity estimates (electricity and fossil fuel, 
respectively) from the EPRI and ANL studies. The SIC codes are grouped according to the energy intensity, so that the most "important" industries are listed first. Those elasticies that are in 'good' agreement across the EPRI studies are shaded. Those that are 'very good' are also in bold. Half of the electricity elasticities are in 'good' agreement, representing $55 \%$ on electricity use. Less than half of the fossil fuel elasticities are in 'good' agreement, representing only $20 \%$ of fossil fuel use.

For the sectors included in the ANL study, i.e., those in either the electric or fuel intensive categories, additional disagreement is found. While one can list many differences between the studies, a major on is in aggregation. The ANL study uses data for the energy intensive three-digit SIC portion of the 2-digit sector to focus on the energy activities more closely. This additional disaggregation is best illustrated by SIC 33, where the first estimate is for the blast furnace and steel mill segment of SIC 33. The second estimate (in parenthesis) is for SIC 3334, primary aluminum. The estimates obtained in the ANL study bound the EPRI study estimates. Another difference between the ANL study and the EPRI study is the specification of technical change. This topic will be discussed in a subsequent section.

Despite a consensus for many sectors, a few general observations may be made. For the more energy intensive sectors the elasticities are usually less than one. This implies energy price increases lead to higher energy expenditures, despite the conservation activities. These higher energy expenditures are besides any expenditures on energy conservation activities, i.e., labor, capital or material expenditures. Absent otiler policies or programs that subsidize conservation investment, higher energy prices lead to higher energy costs. 
Table 1: Example Electricity Elasticities in Econometric Studies

\begin{tabular}{|c|c|c|c|c|c|c|}
\hline \multirow[b]{2}{*}{ Ranking } & \multirow{2}{*}{$\begin{array}{c}1988 \\
\text { gigawatthours }\end{array}$} & \multirow[b]{2}{*}{$\mathrm{SIC}$} & \multicolumn{4}{|c|}{ Electricity Elasticity } \\
\hline & & & $\begin{array}{l}\text { Generalized } \\
\text { Leontief }\end{array}$ & $\begin{array}{c}\text { Static } \\
\text { TRANSLOG }\end{array}$ & $\begin{array}{c}\text { Dynamic } \\
\text { TRANSLOG }\end{array}$ & $\overline{A N L}$ \\
\hline 1 & 149.2 & 33 & 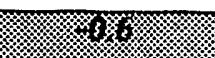 & 83 & (6) & $-0.8(-.1)$ \\
\hline 2 & 121.8 & 28 & -0.2 & -0.8 & $-0.4^{2}$ & 0 \\
\hline 3 & 55.5 & 26 & -0.2 & -0.4 & -0.6 & -0.9 \\
\hline 4 & 50.2 & 20 & \% & 19 & (6\% & -0.4 \\
\hline Sub total & 376.7 & & & & & \\
\hline \multirow{9}{*}{$\%$ of total } & $54 \%$ & & & & & \\
\hline & 37.3 & 37 & $\%$ & 数好 & 剩 & \\
\hline & 33.8 & 32 & -0.3 & * & -0.8 & -0.7 \\
\hline & 33.5 & 35 & w. & (4) & 10 & \\
\hline & 31.8 & 36 & 6. & (x) & 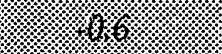 & \\
\hline & 31.3 & 30 & $\sqrt[3]{2}$ & 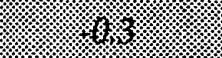 & 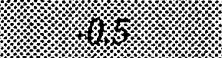 & \\
\hline & 31.1 & 29 & 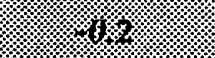 & & 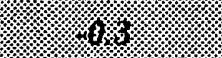 & \\
\hline & 30.9 & 34 & 0.1 & -0.6 & -0.8 & \\
\hline & 29.7 & 22 & -0.2 & -0.5 & -0.7 & -0.2 \\
\hline Sub total & 259.4 & & & & & \\
\hline \multirow[t]{9}{*}{$\%$ of total } & $37 \%$ & & & & & \\
\hline & 17 & 27 & -0.2 & -1.1 & -0.7 & \\
\hline & 16.4 & 24 & -0.8 & -0.3 & -0.9 & \\
\hline & 14.3 & 38 & 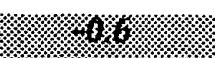 & 14 & 16. & \\
\hline & 6.6 & 23 & -0.2 & -0.7 & -1.0 & \\
\hline & 5.6 & 25 & (19.8 & 6 & 要然桨 & \\
\hline & 4.1 & 39 & -0.4 & -1.0 & -1.3 & \\
\hline & 1.4 & 31 & $1 \%$ & \% & 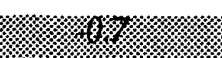 & \\
\hline & 0.8 & 21 & & -0.9 & & \\
\hline Sub total & 66.2 & & & & & \\
\hline$\%$ of total & $9 \%$ & & & & & \\
\hline Grand total & 702.3 & & & & & \\
\hline
\end{tabular}


Table 2: Example Fossil Fuel Elasticities in Econometric Studies

\begin{tabular}{|c|c|c|c|c|c|}
\hline \multirow[b]{2}{*}{ Ranking } & \multirow{2}{*}{$\begin{array}{l}1988 \\
\text { Quads }\end{array}$} & \multirow[b]{2}{*}{ SIC } & \multicolumn{3}{|c|}{ Fossil Elasticities } \\
\hline & & & $\begin{array}{l}\text { Generalized } \\
\text { Leontief }\end{array}$ & $\begin{array}{c}\text { Dynamic } \\
\text { TRANSLOG }\end{array}$ & INRAD \\
\hline 1 & 6.41 & 29 & -0.1 & 1.0 & \\
\hline 2 & 4.36 & 28 & -0.2 & $-(0.6$ & -0.4 \\
\hline 3 & 2.87 & 33 & 椾瑟 & 16 & $-0.2(-2.7)$ \\
\hline 4 & 2.36 & 26 & -0.1 & -0.6 & -0.1 \\
\hline Sub total & 16.002 & & & & \\
\hline \multirow[t]{3}{*}{$\%$ of total } & $78 \%$ & & & & \\
\hline & 0.99 & 20 & 0.0 & -0.8 & -0.5 \\
\hline & 0.97 & 32 & $-(0.1$ & -1.3 & -0.6 \\
\hline Sub total & 1.96 & & & & \\
\hline \multirow[t]{15}{*}{$\%$ of total } & $10 \%$ & & & & \\
\hline & 0.41 & 24 & -0.7 & -1.1 & \\
\hline & 0.35 & 37 & W & \% & \\
\hline & 0.35 & 34 & -0.1 & -0.5 & \\
\hline & 0.28 & 35 & -1.7 & -0.4 & \\
\hline & 0.28 & 22 & 森 & 463 & -0.3 \\
\hline & 0.25 & 30 & -0.7 & 0.0 & \\
\hline & 0.22 & 36 & 16 & 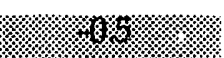 & \\
\hline & 0.11 & 27 & -0.6 & -1.2 & \\
\hline & 0.11 & 38 & -1.3 & -0.3 & \\
\hline & 0.06 & 25 & 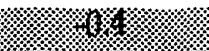 & 46 & \\
\hline & 0.05 & 23 & 26 & $\sqrt{1} \times 1$. & \\
\hline & 0.04 & 39 & (1) & 4 & \\
\hline & 0.03 & 21 & & & \\
\hline & 0.02 & 31 & 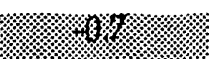 & $4 \%$ & \\
\hline Sub total & 2.56 & & & & \\
\hline$\%$ of total & $12 \%$ & & & & \\
\hline $\begin{array}{l}\text { Grand } \\
\text { total }\end{array}$ & 20.52 & & & & \\
\hline
\end{tabular}




\section{EXAMPLE PRICE RESPONSES IN ENGINEERING (CSC) STUDIES.}

The slope of the CSC caries information about price responsiveness which is very similar to the elasticity. In fact, if the slope of the CSC is transformed by the base energy price to represent a percentage, this yields a type of demand elasticity. This section computes some implied elasticities from the CSC used in the National Energy Strategy (NES) by the FOSSIL II model.

Engineering analysis of energy conservation frequently focuses narrowly on an set of specific processes, i.e. on a specific production step in a specific industry, or on generic energy services. This is the approach used by Fossil II for the aggregate 'industry' sector and also by the NEMS (National Energy Modeling System) industrial model, for energy intensive industry sub-sectors. Generic energy services are inputs that a variety of industries may employ in their production process and require energy to 'produce" the service, e.g. steam, machine drive, or process heat. Three such CSC are shown in figures 2-4. The $x$-axis represent the percent energy savings from a reference level and the $y$-axis gives the marginal capital cost. To convert the marginal capital cost to an equivalent energy price a capital recovery factor $(C R F)$ is required. The CRF is defined as,

$$
C R F=\frac{d}{\left[1-(1+d)^{-n}\right]}
$$

where,

$\mathrm{d}$ is the discount rate and

$\mathrm{n}$ is the capital (or project) lifetime.

The NES (Department of Energy 1991) assumed $d=25 \%$ and $n=25$ years. These values are used to compute the CRF and transform the $y$-axis of figures 2-4 to equivalent energy prices. If one computes the elasticity from the figures by choosing $\$ 4 / \mathrm{mBtu}$ and $\$ 15 / \mathrm{kWh}$ and then doubling then, the change in conservation savings is an approximate elasticity. Table 3 summarizes these results. The elasticities (first column) are very modest and at the low end of those found in tables 1 and 2. The second column gives the amount of conservation that is cost effective at current prices. This is where CSC and econometric analysis depart. The notion that there are unrealized savings at current energy prices.

Table 3: Approximate price elasticities from the Fossil 2 Conservation Supply Curves.

\begin{tabular}{lcc}
\hline Categories & Elasticity & Conservation at "Current Prices" \\
\cline { 2 - 3 } New Machine Drive & -.18 & $10 \%$ \\
$\quad$ Electricity & & \\
New Process Heat & -.11 & $13 \%$ \\
New Steam & -.20 & $10 \%$ \\
\hline
\end{tabular}




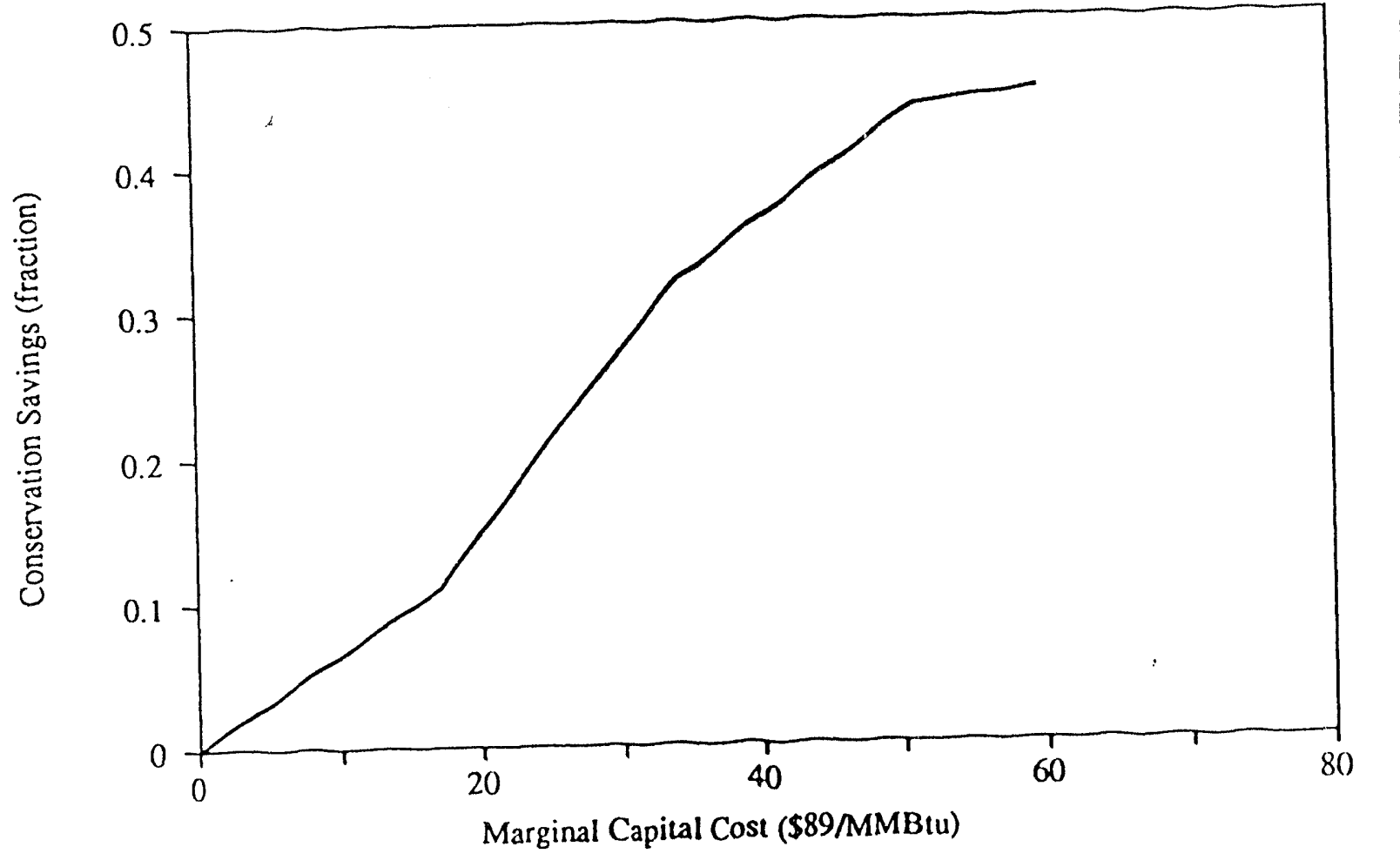

Figure 2 New Industrial Steam Conservation Savings Curve (source: DOE 1991) 


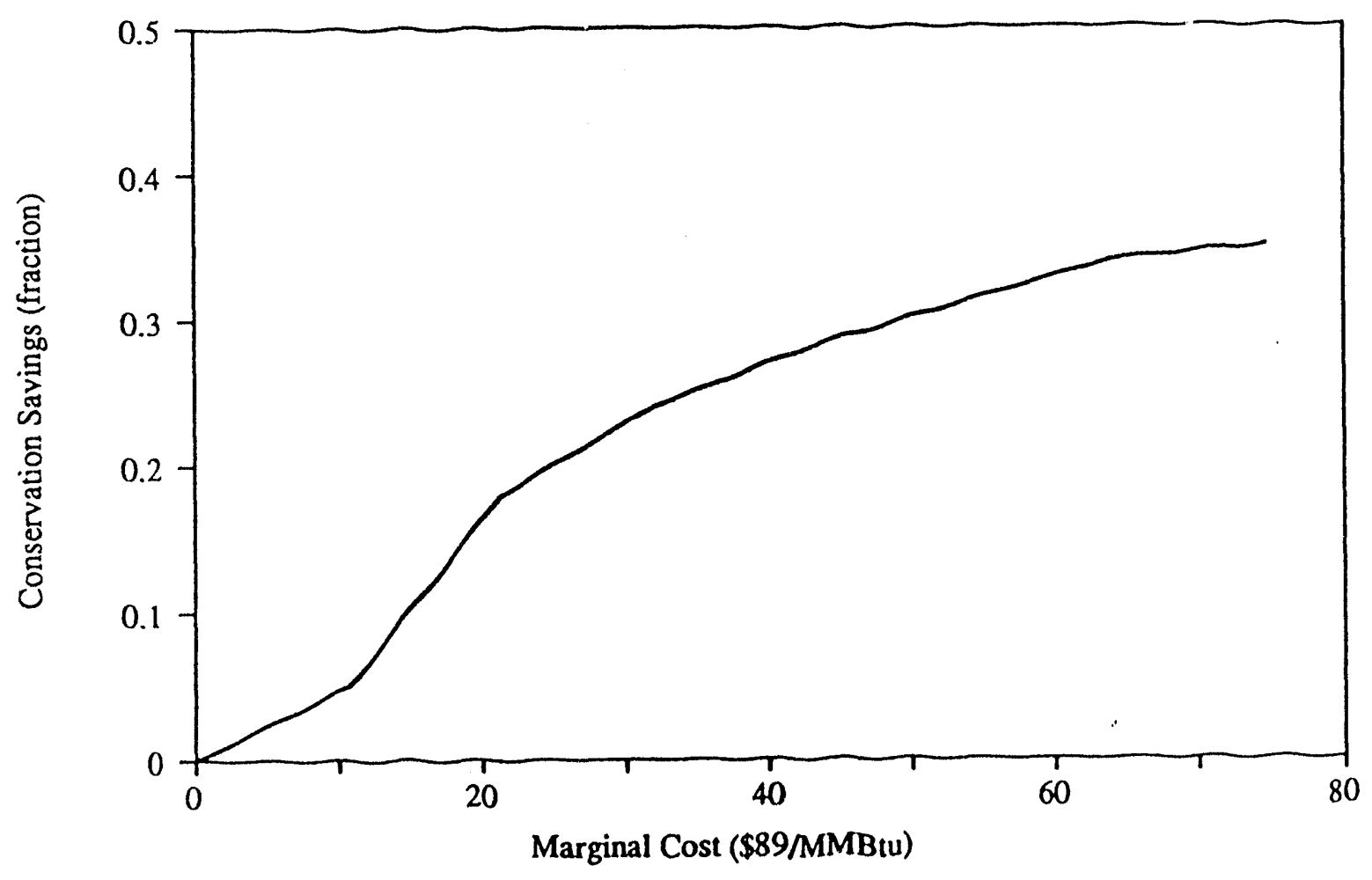

Figure 3 New Industrial Process Heat Conservation Savings Curve (source: DOE 1991) 


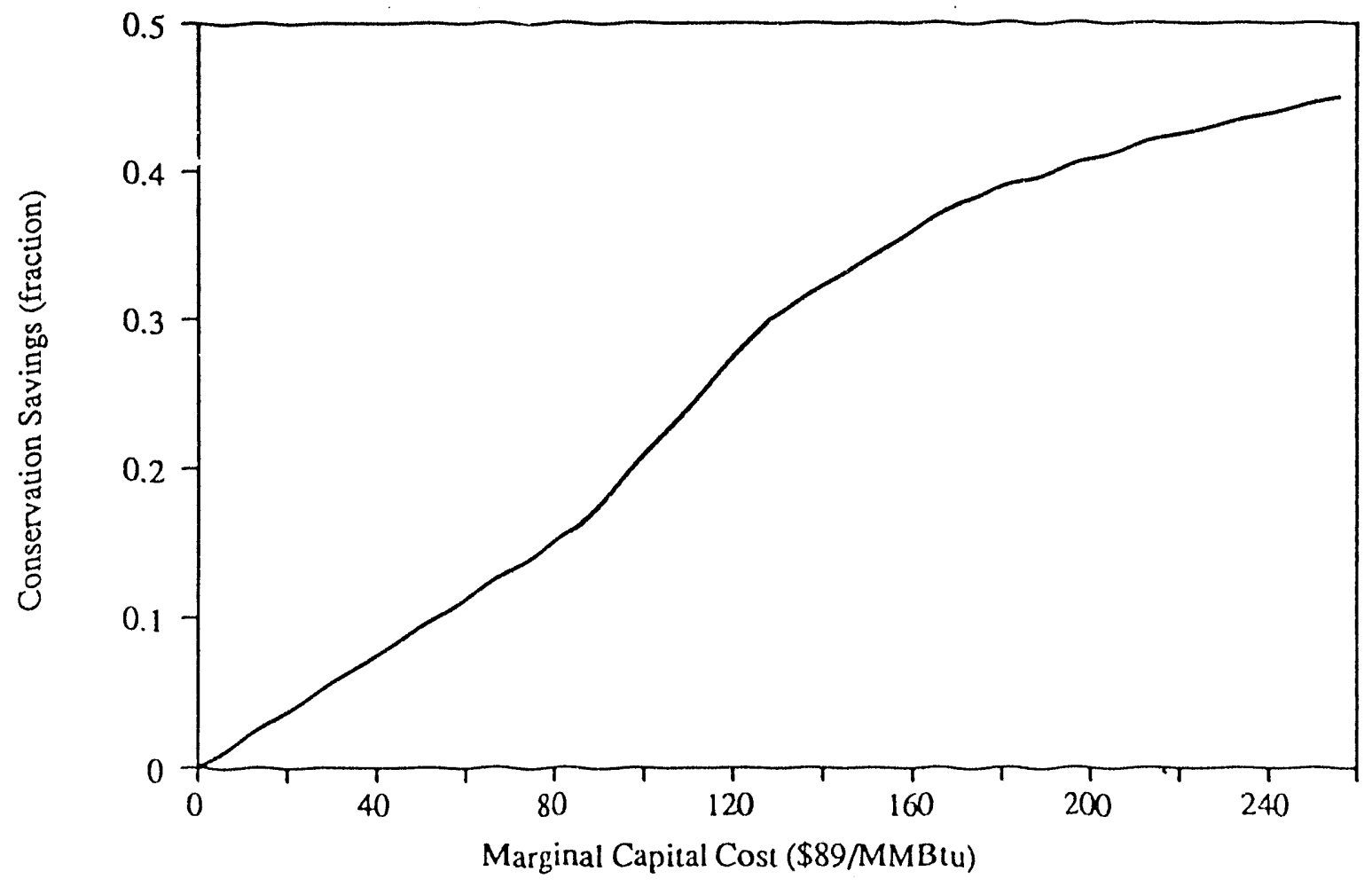

Figure 4 New Industrial Machine Drive Conservation Savings Curve (source: DOE 1991) 
The discount rate (capital recovery factor, hurdle rate, etc.) plays a critical role in estimating the trade-off between fixed capital investment, energy use, and flows of energy services. The NES results discussed above assume a $25 \%$ hurdle rate. Some argue that this is too high; that industry can borrow at a much lower rate. Others argue about risk aversion and the need to use only internal cash for cost cutting measures like energy investments, saving external borrowing only for major processes and product changes. The major effect of a change in discount rate occurs in the CSC computation of the "Current Price" conservation. Under an assumed 12\% discount rate the "Current Price" conservation estimates would be $28 \%, 24 \%$, and $30 \%$ for new machine drive, new process heat, and new steam, respectively.

\section{THE "FREE LUNCH" AND TECHNICAL INEFFICIENCY}

As illustrated above, one characteristic of the CSC is that it (may) predict availability of energy savings at or below current energy prices, the so-called free lunch or negawatts. Such CSC studies show that many technologies (with significant energy savings) are cost effective at current prices. Other may argue that firms do not adopt these technologies due to 'hidden costs' not accounted for by the engineering estimates, e.g. information costs, financial constraints, or some market barriers. The previous section discussed the impact of the capital recovery rate, hurdle rate, etc. on the shape of the CSC. The discount rate clearly has a large impact on the size of these energy savings. This section presents other evidence of the free lunch, i.e. technical inefficiency, in an economic context.

For a variety of reasons some companies/plants perform better than others. One can then identify the 'best practice' plants and compare the rest of the industry to them using techniques developed in frontier production analysis (Fare, Grosskopf, and Lovell 1985). In an initial examination of plants in six energy intensive industries in 1985, (Boyd, Neifer, and Ross 1992) measured the difference between the 'best practice' plants and average plants in the sample (see table 4). While the results are subject to rinany caveats, they found that reductions in energy use from $0.2 \%-23 \%$ might be possible, if all plants could eliminate technical inefficiencies. This falls within the range of estimate from the CSC analysis above. The distinction is that CSC analysis examine the cost effective adoption of specific technologies, while the technical efficiency approach is a relative comparison of the performance of plants in an industry. While there may be overlap within these two approaches they are not measurement of the same concept.

The question arises whether changes in energy prices give incentive to reduce these inefficiencies or whether they are, in some sense structural. Although the estimates of the size of the technical inefficiencies (or CSC free lunch) may differ, there is evidence that inefficiency exists in the industrial sector. Neither engineering nor economic methods suggest how much energy prices are an incentive to reduce this gap between best practice and average industry behavior. If this gap is due to 'hidden' costs, then higher prices can give incentives to close the gap. If they are due to lack of knowledge or experience, then other policy actions are likely to be more useful. 
TABLE 4: Estimates of Energy Consumption under Best Practice Technology Assumptions

\begin{tabular}{|c|c|c|c|}
\hline $\begin{array}{l}\text { SIC Code and } \\
\text { Industry }\end{array}$ & $\begin{array}{c}\text { Actual } \\
\text { Total } \\
\text { Energy } \\
\text { Input }\left(10^{9}\right. \\
\text { Btu) }\end{array}$ & $\begin{array}{l}\text { Best } \\
\text { Practice } \\
\text { Total } \\
\text { Energy } \\
\text { Input } \\
\left(10^{9} \mathrm{Btu}\right)\end{array}$ & $\begin{array}{l}\text { Percentage } \\
\text { Decrease }\end{array}$ \\
\hline $\begin{array}{l}2621 \\
\text { Paper mills }\end{array}$ & $1,080.2$ & 880.4 & 18.5 \\
\hline $\begin{array}{l}2812 \\
\text { Alkalies and } \\
\text { chlorine }\end{array}$ & 147.9 & 147.6 & 0.2 \\
\hline $\begin{array}{l}2873 \\
\text { Nitrogenous } \\
\text { fertilizers }\end{array}$ & 192.9 & 176.6 & 8.4 \\
\hline $\begin{array}{l}3241 \\
\text { Cement, hydraulic }\end{array}$ & 337.7 & 269.4 & 20.2 \\
\hline $\begin{array}{l}3312 \\
\text { Blast furnaces and } \\
\text { steel mills }\end{array}$ & $1,854.6$ & $1,416.5$ & 23.6 \\
\hline $\begin{array}{l}3334 \\
\text { Primary aluminum }\end{array}$ & 245.9 & 231.1 & 6.0 \\
\hline
\end{tabular}

\section{TECHNICAL CHANGE AND ENERGY USE}

Both econometric and engineering analysis have difficulty accounting for changing technology in the industrial sector. In econometric analysis, one typically has little or no information, so technical change in simply a time trend in the cost share or input output ratio. Technical change in simply a continuation of trends that are unexplained by prices or other measured effects. In engineering analysis, there is the problem of having little solid data for technologies that are on the forecast 'horizon' which would be the basis for long term forecasts. The CSC approach is better at examining recent, ongoing changes in industry, however. The importance of treatment of technical change centers on the question "How much of observed energy use (conservation) is due to price motivated technology adoption and how much is simply the use of new technology 
that is 'state of the art' that would be adopted under 'any price' ? A potentially useful distinction is technology that is a fundamental change versus those that are incremental. Fundamental change represents a 'very different' way of making a product (or providing an energy service) while incremental change represents an improvement in the existing technology. Theory suggests that for risk adverse firms, fundamental change requires larger inducements to adopt, i.e. larger energy prices or better demonstration of the benefits of the technology.

New technologies need not be energy-saving; they may be energy-using. The best example of this is electrification of some industrial processes. From an engineering prospective this involves modeling boin the increased use of electricity in some production stages while modeling electricity conservation in other production stages. In econometric analysis, energy-using technical change is 'factor biased', i.e. the bias toward using more electricity in a industrial sector. Factor biaser change may also be energy saving, representing the kind of new technologies that save energy 'at any price' mentioned in the previous paragraph. To better understand the role of prices in energy decisions a better understanding of new technology is required.

Boyd, Kokkelenberg, and Ross (Boyd, Kokklenberg, and Ross 1991) examine this issue econometrically by including the market share of major electric based processes in two industries. Thermomechanical pulping (TMP) and electric arc furnaces (EAF) are two electricity intensive technology trends in the paper and steel industries, respectively. Table 5 shows the impact on the estimated price elasticities of using a traditional factor-biased measure, i.e. time trend, versus the technology specific measure, market share of TMP and EAF. The technology based technical change yields larger electricity elasticities in both sectors and smaller fossil fuel elasticities in paper. Given the caveats about the wide variation in elasticity estimates one can still observe that the underlying representation of technical trends is very important.

One final observation about technical change and price. There has not been much treatment of the issue of price induced technology change, i.e. the development of new technology in response to a new energy price regime. In some sense, the emergence and growth of several DOE offices reflect this response. To understand how higher energy prices might effect energy use in the long run this effect will need to be better understood. 
Table 5 Comparison of Elasticities with Alternative Specification of Technical Change

\begin{tabular}{|c|c|c|c|c|c|}
\hline \multirow{2}{*}{$\begin{array}{l}\text { Industry } \\
\text { Description }\end{array}$} & \multirow[b]{2}{*}{ SIC } & \multicolumn{2}{|c|}{$\begin{array}{l}\text { Factor-Biased } \\
\text { Measure }\end{array}$} & \multicolumn{2}{|c|}{$\begin{array}{c}\text { Technology-Specific } \\
\text { Measure }\end{array}$} \\
\hline & & $\begin{array}{l}\text { Fossil } \\
\text { Fuel }\end{array}$ & Electricity & $\begin{array}{l}\text { Fossil } \\
\text { Fuel }\end{array}$ & Electricity \\
\hline $\begin{array}{l}\text { Upstream } \\
\text { paper }\end{array}$ & $26 \mathrm{U}$ & -0.49 & -0.85 & -019 & 116 \\
\hline $\begin{array}{l}\text { Ferrous } \\
\text { metals }\end{array}$ & $33 \mathrm{FE}$ & -0.12 & -0.43 & -0.17 & -0.77 \\
\hline
\end{tabular}

\section{ENERGY PRICES, TECHNOLOGY AND PRODUCTIVITY}

The previous section presents evidence that the way in which technological change enters the analysis impact on the estimate of energy price effects. This section examines a related issue, "Do energy prices effect productivity?". Econometric analysis presented in this paper allow for the possibility that new technology is biased in its use of inputs, e.g. TMP and EAF are electricity using technologies.

Economic theory then predicts what the result of an energy-using bias in some industries (e.g. electrification) is higher energy prices would adversely impact on that industry's productivity growth. The EPRI study discussed above found from $75 \%-95 \%$ of the industries modeled to show electricity using biases. A wider range, 25\%-75\%, exhibited fossil energy using bias. When we examine the technical biases of the five most energy intensive sectors, SIC $26,28,29,32$, and 33 , the estimates found $80 \%-100 \%$ of the sectors were electricity using. There is no agreement regarding fossil fuels. One functional form, the Generalized Leontief, found energy saving bias in all sectors while the static TRANSLOG found only one to be energy saving. The ANL study found fossil fuel saving in $80 \%$ of the energy intensive sectors. The ANL study used the Generalized Leontief functional form as well.

If the EPRI and ANL studies are representative, then electricity use is an important source of productivity. This in turn implies that higher electricity prices would have adverse effects on productivity for many sectors. This is the same story that is chronicled by Schurr (Schurr et al. 1990). They argue that electricity is instrumental in organizing production in general. They also illustrate how electrotechnologies like EAF, TMP and others, play important process specific roles in the energy intensive materials processing sectors.

The story behind fossil fuel use is not as clear. Some studies point to technical 
change reducing the role of fossil fuel use. This is frequently the other side of electrification. To the extent that this is the case then higher fossil fuel prices have less direct impact on industrial productivity. However, it is important to note that higher fossil fuel prices will lead indirectly to higher electric prices. So that the conclusion that higher energy prices, in general, would adversely effect productivity is likely.

\section{CONCLUSION}

This paper raises some of the issues that surround the question, "What impact do higher energy have and conservation and productivity?" This workshop will examine some of the other non-price issues that have been alluded to in this paper. When one looks at price response estimates we find a wide range of estimates, suggesting that there are many factors that influence the industry, firm, or plants ability to adapt to (or mitigate) higher energy prices. The range of estimates suggest modest, but not inconsequential ability to adjust to higher prices, but that energy expenditures still rise when prices rise, i.e. other inputs cannot completely substitute for energy. Evidence about the conservation "free lunch" and plant studies of technical inefficiency also suggest that there are gains to be made, but one again it is not clear that energy prices alone give the incentive to reduce these inefficiencies. Both economic and engineering anecdotal evidence suggest that electricity is an important vehicle for technical change and productivity, so higher energy prices, particularly in the form of higher electricity prices, could slow productivity growth. How new technologies move into the market is the essence of this question of whether higher energy prices will spur more conservation. This appears to be an largely unanswered question.

This author suggests several important avenues of exploration to illuminate these problems.

The foremost is capital turnover. This relates to the timing of new technology introduction, i.e. does the "state of the art" only come into new plants as an industry grows or old facilities are shut down or refurbished.

The second is (possible) practices of capital rationing. This can be best viewed from the perspective of the CSC and the ability of firms or plants to invest in cost-cutting investments at close to a market rate of return.

The last is how long run technology development may be spurred by higher energy prices. This has to do with the $R \& D$ side of industrial energy technologies.

Examining these issues may help understand the conservation issues of new technology adoption and whether industry will need to pay itself (in the form of higher energy prices) to eat the conservation "free lunch" . 


\section{REFERENCES}

Boyd, Gale, Edward Kokklenberg, and Marc Ross, 1991, Technology Trends in Econometric Energy Models: Ignorance or Information?, IAEE 13th Annual North American Meetings, Chicayo, IL

Boyd, Gale, Mark Neifer, and Marc Ross, 1992, Modeling Plant-Level Industrial Energy Demand with the Longitudinal Research Database and Manufacturing Energy Consumption Survey Database, Argonne National Laboratory Report ANL/EAIS/TM-96.

Boyd, Gale A., Edward C. Kokklenberg, and Marc H. Ross, 1991, Sectoral Electricity and Fossil Fuel Demand in U.S. Manufacturing: Development of the Industrial Regional Activity and Energy Demand (INRAD) Model, Argonne National Laboratory Report ANL/EAIS/TM-35.

Department of Energy, 1991, Integrated Analysis supporting the National Energy Strategy: Methodology, Assumptions and Results, Department of Energy Report DOE/S-0086P.

Fare, Rolf, Shawna Grosskopf, and C.A. Knox Lovell, 1985, The Measurement of Efficiency of Production. Edited by A. Dogramaci, Studies in Productivity Analysis, Boston: Kluwer-Nijhoff.

King, Michael J., 1990, Guide to the INDEPTH Level 1 Econometric Models: Final Report, Electric Power Research Institute

Schurr, Sam, Calvin Burwell, Warren Devine, and Sidney Sonenblum, 1990, Electricity in the American Economy. New York: Greenwood Press.

Solow, J. L., 1987, The Capital Energy Complementarity Debate Revisited, American Economic Review, 77 : 605-14. 

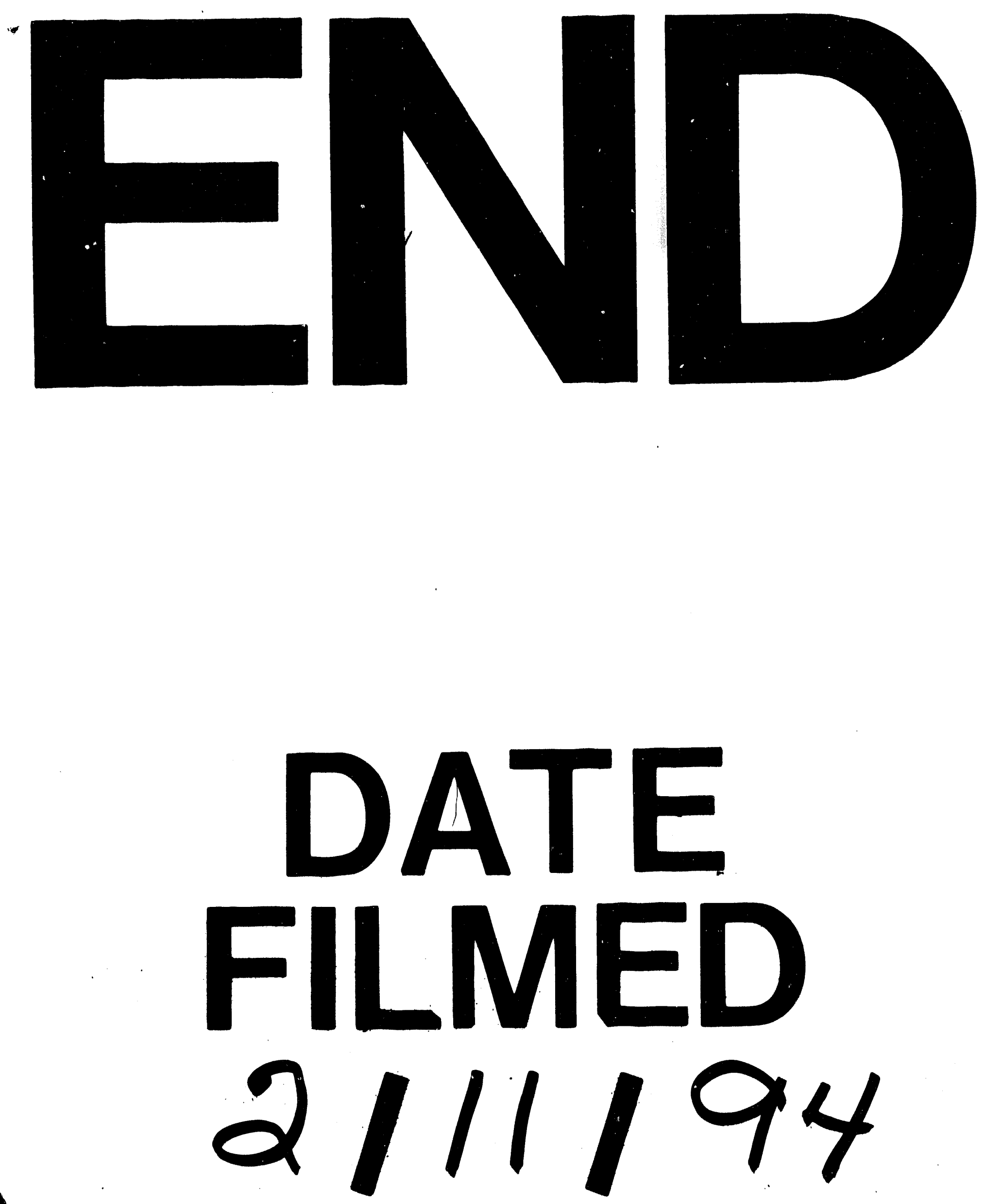
